Соња М. Миловановић*

Радио-телевизија Србије

Радио Београд

https://doi.org/10.18485/ai_beckovic.2019.ch12

821.163.41.09-1 Бећковић М.

\title{
О ЕГЗИСТЕНЦИЈАЛНОМ У ПОЕМИ КАД ДОЂЕШ У БИЛО КОЈИ ГРАД МАТИЈЕ БЕЋКОВИЋА
}

Полазећи од семантике глагола доћи у контексту поеме Кад дођеш у било који град Матије Бећковића, у раду испитујемо проблем времена, односно временитости, како бисмо сагледали на које се начине реализује егзистенцијално као један од најважнијих идејних слојева поеме. Егзистенцијалну димензију испитујемо издвајањем појединих језичких реализација категорије егзистенције или пак импликација ове категорије, те на основу тога утврђујемо примарни и секундарни, односно спољашњи и унутрашњи егзистенцијални план. Са овим другим у вези указује се на драмско бивствовање и аргументацијски дискурс, те тиме открива „расправљани свет” поеме.

Кључне речи: егзистенција, време, бивствовање, глаголски аспект, драмско, расправљани свет

Средиште Бећковићевог лирског љубавног триптиха, поема Кад дођеш у било који град, преко мотива мртве драге, односно идеје судбинског пута на којем је уписан судбински сусрет са вољеном женом, развија егзистенцијалну димензију као равноправну са љубавном и религиозном. Егзистенцијални слој је, поред тога, једна од диференцијалних црта ове исповедне поеме у односу на 
реторски обојену прву (Вера Павладољска) и химнички интонирану последњу (Парусија за Веру Павладољску) поему овог триптиха ${ }^{1}$.

Феномен егзистенције сам по себи веома је широк, и често му се приступа интердисциплинарно: „Категорија егзистенције (постојања, бивствовања) једна је од основних филозофских, појмовних и семантичких категорија која - може се рећи - одувек привлачи пажњу филозофа и лингвиста. [...] Филозофско и онтолошко промишљање идеје постојања, те спознаја и одређење схватања постојања уопште, централни су мисаони проблеми још од Аристотелове Метабфизике до филозофије новијег времена (Хајдегера, Сартра, Јасперсена), која уз феномен егзистенције у центар пажње ставља и проблем постојања човека као јединке, приближавајући на тај начин филозофску парадигму проблема лингвистичкој, нарочито оној антрополошког усмерења" (Лазић-Коњик 2009: 359). Сходно феномену егзистенције, и феномен времена често се проматра интердисциплинарно, те се о времену може говорити као о објективном времену, или времену света, и субјективном времену, или времену душе (в. нпр. Антонић 2001: 43, Бечановић-Николић 1998: 144).

У Бећковићевој поеми Кад дођеш у било који град управо су предочена два типа времена, па и егзистенцију, у контексту ове поеме, разматрамо као двојако остварену: као спољашњу (експлицитну) и унутрашњу (имплицитну). При томе се водимо и лингвистичким, односно семантичким одређењем категорије егзистен-

1 Запажено је да поема Кад дођеш у било који град није „тек и једино льубавна", већ да се успоставља однос са историјским слојем Бећковићевог песништва, као и да се у њој распознају егзистенцијална тематика и религијска основа (Поповић 2012: 272). Заправо, „религиозно и егзистенцијално се узајамно одређују" (Радуловић 2012: 326), али док је Парусија пре свега химничка песма, „Кад дођеш y било који град превасходно је исповедна, љубавно-мисаона, са тихом и сетном упитаношћу" (Јовановић 2012: 307). 
ције, и њеним онтолошким импликацијама. Сематичко одређење егзистенције утврђује се путем функционално семантичког поља егзистенције: „Категорија егзистенције је сложена семантичка категорија вишеслојне структуре. Обухвата варијантна значења постојања, бивствовања, присуствовања, те различите видове, начине и фазе постојања, што се неминовно одражава на бројност и разноврсност језичких средстава којима се сва та значења изражавају. У основи функционално-семантичког поља егзистенције је (функционално-) семантичка категорија постојања као његова семантичка доминанта, која обједињује основно значење 'бити, постојати' и варијантна значења, нпр. 'живети', 'присуствовати', 'налазити се', фазна значења почетка, постанка, трајања, континуитета, завршетка, нестанка и др.” (Лазић-Коњик 2009: 363). Одређена филозофска усмерења такође у фокус стављају проблем егзистенције као бивствовање-у-свету или тубивствовање (Хајдегер), а што је у директној вези са појмом времена, односно временитости.

А проблем времена, а преко њега и проблем егзистенцијалног, један је од кључних у Бећковићевој поеми Кад дођеш убило који град. ${ }^{2}$ Да време није једноставно одредити (Јовановић 2012: 302), као и да је реч о свевремену (Делић 2006: 31) произилази из преплета и укрштаја појединачног и општег (Делић 2006: 33) и евокацији „јаких егзистенцијалних садржаја" (Пантић 2002: 68), иначе доминантних Бећковићевих песничких поступака у конфигурацији текста. Установљено је при томе да је реч и о

2 Књижевна критика истакла је време међу најважније елементе текста, који, поред композиционих, природе песничког субјекта, односно казивача, динамичног „ја-ти” односа, симболике пута и града, до интертекстуалних веза како са библијским предлошком тако и са остала два поетска састава љубавног триптиха чини ову поему изразито вишеслојном и динамичном (в. посебно Делић 2006, Јовановић 2012). 
тренутку и вечности, светом и световном времену (Јовановић 2012: 302), да се у тренутку казивања поеме желе обухватити сва времена - прошлост, садашњост, будућност, на основу чега лична прича постаје општеважећа, те како се лично искуство универзализује и митологизује (Делић 2006: 31, 33). Но о времену се може говорити као о расправљаном и приповедном времену (Вајнрих 1989), односно приповедном времену и временитости, о чему ће посебно бити речи у овом раду. Временитост се пак, као што је речено, директно односи на егзистенцијални слој, што се у поеми наговештава, како ћемо настојати да покажемо, путем семантике глагола доћи. Зашто егзистенцијално проматрати полазећи од глагола доћu, и зашто се проблему времена може прићи пратећи његову семантику у контексту поеме, указује већ уводни сегмент, којим се, услед прстенасте композиције, поема и завршава:

Кад дођеш у било који град

А у било који град се долази врло касно

Кад врло касно дођеш у било који град

Доћи ћеш путем којим си морао доћи

Који пре тебе није постојао

Него се с тобом родио

Да идеш својим путем

И сретнеш ону коју мораш срести

На путу којим мораш ићи

Која је била твој живот

И пре него што си је срео

И знао да постоји

И она и град у који си дошао

Бећковићев поетички поступак уопштавања и упосебљавања ствари уочљив је већ на почетку поеме: надовезивањем општег на појединачно, а заправо подвођењем појединачног под опште - што је у првим стихо- 
вима изражено личном па обезличеном конструкцијом (кад дођеш: се долази), у ономе, дакле, што важи и у конкретном као и у општем случају.

Управо двострукост „виђења” ствари - кроз општи и појединачни план, која се тиче и двоструког тона који казивач поеме заузима - са једне стране тежи гномичности, те стога и „пророчком стилском синдрому” (Пантић: 2002), а с друге истиче појединачност као меру ствари, директно се тиче и односа према времену. Тај је однос вишеструко динамизован кроз наративно ткиво текста, што је експлицирано низом језичких показатеља различитих временских релација 3 .

Конкретно, два су тока којима се у поеми комплекс времена оспољава. Један је онај који се односи на временске релације непосредно језички предочене или посредно сугерисане неким језичким сигналом, а који се тиче физичке представе времена, други на унутрашњу драматизацију времена песничког субјекта, односно казивача ${ }^{4}$. Први слој овог комплекса најочитији је у употреби глагола, прилога, везника са временским значењем, чија фреквенција говори о важности самог проблема времена у поеми. Тако се, рецимо, поема отвара темпоралном кла-

3 У читавој поеми сукцесивни и симултани временски односи, односно - антериорност, постериорност и симултаност разноврсно су предочени - што се, између осталог, најбоље прати употребом везника и везничких спојева - кад, док, чим, пре него што... Преплет три временске сфере - садашњости, прошлости и будућности, и њихово сажимање у доживљај времена као слике животног пута предочава модални карактер употребе времена. Став говорног лица према ономе што казује, односно субјективни доживљај времена уочљив је и употребом речце већ „као неочекивано ране реализације радње” (Ковачевић 2006: 310), али и обликом футура, који је већ по пореклу у вези са модалним значењем, односно сфере будућности у којој је тешко разграничити временско од модалног значења (Милошевић 1970: 73-74).

4 Термин казивач за Бећковићеву поезију уводи J. Делић (1995: 46). 
узом (кад дођеш) и футуром у управној клаузи (доћи ћеш), везницима временског значења (пре него што, чим, док, кад), потом прилозима за обележавање времена (одувек), именицама (вековима, године) и друго.

Посреднији однос према времену као да је наговештен у уводном певању, а који посредством семантике глагола доћu, односно синтаксичког оквира у којем се предочава радња исказана датим глаголом, имплицира двострукост кретања - и као нужности и као одлучности, истовремено, дакле, и као неизбежне и као вољне радње. То се пре свега истиче на текстуалном плану, будући да је функција датог глагола, а са њиме и уводних стихова који готово да добијају функцију формуле, овде релевантна на нивоу текста, а не (само) реченице. Штавише, у обзир треба узети говорну ситуацију, на основу које разликујемо расправљани и приповедни свет, а која је за рецепцију текста у директној вези са употребом одређеног глаголског времена (уп. Вајнрих 1989: 215-220). Али пре разматрања те поделе, вратимо се семантици глагола доћи.

Пошто је глагол доћи употребљен и у зависној и у управној клаузи, а да су обе клаузе због „бокорења” исказа ${ }^{5}$ слике за себе, поставља се питање према којем доћи се превасходно, комуникативно али и афективно, оријентишемо - према доћи из кад-клаузе (темпоралне) или из управне? Да ли је самим тим реч о истоветним радњама изреченим истим глаголом? Да ли обична чињеница о томе да кад неко дође дошао је, овде (у контексту) постаје онеобичена? Пошто имамо исту глаголску лексему, да ли је реч о симултаним или сукцесивним

5 Бокорење исказа или техника ризома једна је од стилских доминанти Матије Бећковића. О овом поступку говори П. Милосављевић (1999:167). У нашем случају, обе клаузе веома су разгранате структуре, где прва развија слику доласка, града, уз наглашавање става да је сваки долазак окаснео, а структура управне слику пута (кретања), судбинског сусрета, спознају. 
радњама? Шта, заправо, ствара извесну напетост између те две клаузе или микрослике, сугерише ли се тиме некакав заплет? Низ постављених питања упућује најмање на два проблема на која ћемо, из угла лингвостилистике, покушати да одговоримо: каква је слика времена и какав је карактер времена о којем се у поеми говори.

У оквиру семантике глагола, категорија аспектуалности, односно темпорално-аспектуалних односа, и њен подтип - проспективност, полазиште су за испитивање поменутих дилема које се јављају у вези са уводним сегментом, а који се, у варијацијама, јавља дуж читаве поеме, односно текста у целини. Под аспектуалношћу се подразумева да „у исказивању временских односа могу бити важни - не читави периоди у оквиру којих се неки догађај одиграва, него временске границе неког догађаја [...] Предикати с глаголима као што су донети, довући, дописати стављају у фокус завршну границу догађаја о којем се предикатом нешто саопштава (Пипер 2005: 781), а „суштина перфективности као маркираног члана у аспектуалној опозицији перфективност / имперфективност јесте у временском 'уобличавању' предикатске радње или стања истицањем њених граничних тачака, пре којих или после којих уместо те радње или стања имамо неку другу радњу или неко друго стање" (Пипер 2005: 782).

Када је реч о промени радње или стања, односно истицања њихових граничних тачака, поред семантике глагола доћи индикативна је и временска сфера. Пошто је реченична предикација у футуру који даје податак о сфери будућности, а уз то је у предикату глагол кретања, овде је реч о проспективној или претпочетној фази радње. „Проспективност или претпочетна фаза радње је везана за будућност која се приближава, стога је у изражавању ове фазне карактеристике значајан удео семан-

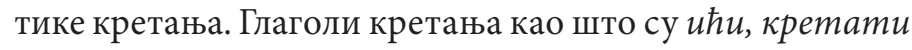
и сл. подједнако се често користе у значењу припремне 
фазе реализације будуће радње у многим језицима. [...] У словенским језицима могуће је везиваюе проспективности за прошлост која се пред очима говорника претвара у будућност, чиме се фактички занемарује план садашъости, тј. истиче се не спремност, већ тренутак доночена одлуке. Одлука је донета у најближој прошлости која се подудара са моментом говора и после те наступа будући план (С.М.) (Поповић 2008: 173-174). Будућност овде није само језички посредован феномен, већ и онтолошки, или, Хајдегеровим језиком речено, са̂мо тубивствовање. Смисао времена „досеже се путем анализе бивствовања-ка-смрти и аутентичног бивствовања”, те „постаје део комплексне егзистенцијалне проблематике (Бечановић-Николић 1998: 149). А за бивствовање субјекта сада и овде примаран је план будућности „jер је тубивствовање усмерено ка смрти и ка прилажењу самоме себи” (1998: 150). „Прошлост и садашњост су за Хајдегерово схватање битне утолико што представљају импликације будућности, садржане су у будућности као део прилажења-ка-себи (1998: 150). Дакле, у том контексту, и глагол доћu, означавајући будућу радњу, у најужој је вези са димензијом егзистенцијалног.

Удео воље, одлуке, и поред нужности онога што је писано да буде, а што је истакнуто троструким понављањем глагола морати, којим се подвлачи нужност а искључује случајност (Делић 2006: 34), проналазимо у стиховима из другог и трећег сегмента: Кад одеш од своје куће/ Било куда/ Само да што пре одеш; односно: А ко год одлучи да путује/ Мора кренути једног дана.

С обзиром на то да овде вољна радња постоји, било имплицитно $(\text { само })^{6}$, било експлицитно (ко год одлучи),

6 Речца само у везничкој служби овде је у функцији појачавања и наглашавања намере или жеље (в. РМС 1973: 622), мада може вршити и прилошку службу када са речцом $\partial a$,истиче тренутак пред свршетак радње или стања: тек што није” (1973: 621). 
чини се да у синтагми кад дође с почетка песме није реч само о временском, већ да са њим интерферира и узрочно, односно условно значење кад-клаузе (в. нпр. Танасић 2012, Ковачевић 2012: 34). Зато лексички истоветан глагол, истог видског лика, неће имати идентичан смисао у оба реченична дела, јер се у зависној клаузи претпоставља воља, вољна одлука о кретању, а у управној се воља подводи под неизбежност, задатост. Тако je, у реконфигурацији текста, на микроплану видљива „напетост” у опозицијама вољно - задато, слобода одлуке - неминовност.

Још нешто ствара тензију када је о појму доласка у овој поеми реч. Наиме, гледано из угла проспективности, овде се укрштају и преплићу различита поља аспектуалности у семантичкој структури глагола доћи као постојања, или постајања, тачније глагола који у контексту развија такво значење - и његово трајање и претпочетну фазу, а која је везана за његову блиску будућност ${ }^{7}$. Зато, чини се, успевамо да помиримо сучељеност резултативног и процесуалног плана радње исказане глаголом доћи и сам процес долажења, односно долазак као процес, што је пак предочено и планом будућности и наративним током поеме. Тако је већ у самом чину доласка као вољне и детерминисане радње уписана напетост која повезује физичко (објективно) са психолошким (субјективним) временом.

Вероватно да су врхунац тог преплета наредни стихови, у којим се глаголом наилази предочава оно што

7 „У једном глаголу могу бити удружена значења да нешто предстоји и да се зачиње, или значења зачињања и приближавања, и не само то, могу бити испреплетана значења претпостојања и постанка, појављивања, фазе која следи за претпостојањем (фаза почетка постојања) - постајати, наилазити и сл." (Лазић-Коњик 2011: 676) 
ће тек доћи, а презентативом ево сама садашњост садашњости ${ }^{8}$ :

и ево наилази оно доба године

или твога живота

кад су све жене она

Управо је овде најуочљивији спој два виђења времена које Бећковић спроводи у песми, митског и психолошког, или космичког и феноменолошког. Космичко време, оно које се мери календарима и часовницима, само је оквир у који се смешта доживљај душе или време живота, односно феноменолошко време. Насупрот обичном, физичком времену (оно доба године), стоји сећање и очекивање, растезање душе (доба твога живота), или тубивствовање, бивствовање ка смрти, што пак предочавају наредни стихови:

И да живимо хиљаде година

прошле би као једна

Јер године су ту да дођу и оду

Али све што је њино

Није Вера Павладољска.

Иако се о егзистенцијалном може говорити према функционално семантичком пољу егзистенције, које у овој поеми репрезентује низ глагола ужег центра (бити, постојати, живети, имати) и најужег, тј. универзалног средства изражавања егзистенцијалне ситуације (бити)

8 Овде се алудира на Августиново схватање троструке садашњости, или на Хусерлово „сада” као „лонгитудиналну интенционалност", дакле не као пунктуелни тренутак, већ као спој самог „сада”, ретенције као свести о ономе што је управо протекло, и протенције као антиципирања наступајуће фазе” (Бечановић-Николић 1998: 147). 
(в. Лазић Коњик 2009: 365-366), у дословном или пренесеном значењу 9 , о њему се може говорити и из домена бриге, у хајдегеровском смислу речи, као бивствовања-у-свету (тубивствовања) ${ }^{10}$ :

Окружиће те деца као сваког придошлицу

И у целом граду нећеш познавати никог

Јер су сви отишли

И с тим би се некако помирио

Али нико се не враћа

Све је готово а још никога нема

Нити има чврстих обећања

Да ћемо се поново срести

И то је оно што највише забрињава

Тренутак који нас се дојми јесте тренутак садашњости који упризорује нову егзистенцијалну ситуацију - усамљеност, и зебњу да та ситуација постаје једина извесност, јер је све друго неизвесно. Говорна ситуација овде је истовремено и позорница догађаја (Вајнрих 1989: 219), због чега су и „егзистенција говорника и слуша-

9 Интересантно је како се семантика постојања - која има своју скалу од почетка постојања до непостојања - лексички реализује у односу лирско ја : вољена жена. Наиме, да одлазак вољене жене није уједно и њена смрт, предочава се у исказима, односно лексемама: она се одмара од тебе и свог имена, коначно се у облаке преселила, рађа се све свиленијег осмеха/ и нема ништа са гроблем и смрћу, док за песничко ја стоји да је коначно и у односу на овај свет: можеш мирно склопити очи/ јер си већ умро и већ васкрснуо. Ипак, завршетак егзистенције овде не значи да је реч о непостојању, већ се слути поновни долазак, те тако доћи осим фазе завршетка радње имплицира и претпочетну фазу радње, те тако указује на онтолошки смисао.

10 Хајдегерово разматрање битка тубитка као бриге (2007:230), много је комплексније од онога што је нама важно у датом тексту, али израста из самог одређења бриге као бивствовања тубивствовања, као егзистенцијално-онтолошке структуре. 
теља" активне, позорне. То је тренутак раправљаног времена, а оно је исказано глаголским презентом. За разлику од приповеднога времена које је „индиферентно према нашем времену", говорна ситуација која се односи на садашњост је „квалитативно маркирана” (1989: 219). Разлика није у томе, како објашњава Вајнрих, зато што певам упућује на садашњост, а певао сам на прошлост, већ зато што нас презент или перфекат информишу о томе како треба да слушамо. Они нам говоре о томе да ли ће певане бити расправљано или приповедано. „Расправљано пјевање захтијева обично тренутачни став: мишљење, вредновање, исправак, или слично. Ако се пак пјевање 'само' приповједа, заузимање става опћенито није хитно. Може се одгодити или чак сасвим изостати” (1989: 218).

Да је посреди став, мишљење, вредновање и слично, указује и то што темпоралност као бивстовање песник покушава да разреши мисаоно, рационално, аргументовано, о чему резонује тренутак касније:

па ипак човек није мање него вода

па вода не умире

нити је смрт нешто

што се на свету догађа први пут

Иако је говорна ситуација, може се рећи, формално приповедна (јер је реч о поеми и казивачу који приповеда свој животни пут), њена унутрушња композиција је расправљачка, не само по функцији обраћања - и себи и другоме, који су заправо две инстанце истог (Јовановић 2012: 298), него и по стилу коментара, разматрања сопственог пута, а што се језички изражава употребом везника јер као општеузрочног везника и супротног везника али. Аргументацијски дискурс, односно исказ, проведен је кроз целу поему, а управо он и упућује на драмски стил, јер, како вели Штајгер, у драмском бивствовању човек не посматра него 
просуђује: „Мера, смисао, поредак, које је посматрач током свог епског путовања схватао уз помоћ ствари и људи, сада се одвајају од предмета и схватају се и потврђују апстрактно, тако да ново стиче важење само у односу на ту 'предрасуду’. План света се кристализовао. Свет, духовно биће постају 'апсолутни', што значи 'одвојени', и у том одвајању 'напросто важећи'. Са такве висине драматичар гледа свет који се мења." (1978: 188). Драматичар-песник конфигурише свет као такав, „напросто вежећи”, због чега се његова прича доживљава као свачија прича.

Мада у овој љубавно-мисаоној поеми није предочен непосредан сусрет са вољеном женом, закулисно нам је представљена драматизација сазнања о досуђеном путу. Управо је та драматизација сазнања други слој драмског, односно егзистенцијалног у ужем (имплицитном) смислу. Смисао доласка није у томе да се пређе из једне просторне тачке у другу, већ оно што сам тај прелазак омогућује самоосвешћење сопственог животног пута. Тај је прелазак предочен као процес од нечега што казивач није знао (која је била твој живот/ и пре него што си је срео/ и знао да постоји/ и она и град у који си дошао) до, освртом на пређени пут, тренутка присећања (све ће ти бити однекуд познато/ као полубаи, већ даван некоме), на оно што је у моменту сусрета спознао (а чим си је видео/ одувек си је волео/ и унапред оплакивао растанак/ који се збио/ пре него што си је срео/ Јер постоји само један град [...] и једна уста која су је рекла/ а по свему како су је изговорила/ знао си да је изговарају први пут/ и да можеш мирно склопити очи јер си већ умро и већ васкрснуо/ и поновило се оно ито никада није било). Дакле, у томе знати распознаје се доживљено време, егзистенцијална битка, оно које Августин разуме као distention animi, растезање душе.

Сам је егзистенцијални моменат као криза сопства заплет поеме, и уједно њен климакс. Јер иако нема радње у класичном смислу речи, „под радњом морамо разумети 
више од понашања протагониста које доводи до видљивих промена стања, више од преокрета судбине, онога што називамо спољашњом судбином појединца. Радња je, у проширеном смислу, и морални преображај лика, његов развој и његово образовање, његово улажење у сложеност моралног и афективног живота. У радњу се, најзад, убрајају, у једном још суптилнијем смислу, и чисто унутрашње промене које се тичу самог временског протока сензација, емоција, све до најмање конкретног, најмање свесног нивоа до којег интроспекција може досегнути” (Рикер, према Бечановић-Николић 1998: 221).

Егзистенцијално се овде доводи у везу са спознајним, па се тако на фону митског као једног начина реализације егзистенције, осликало психолошко, индивидуално, субјективно време. Зато се у поеми, сходно двоструком предочавању времена (космолошком и феноменолошком) и може говорити о две врсте каузалости - митске и аргументацијске, које једна другој нису супротстављене, већ у конфигурацији текста, тачније у свести казивача који тежи да разуме своју судбину, те две аргументације, као два виђења света, егзистенције и времена, коегзистирају. У том смислу покушали смо да предочимо и егзистенцијално у његовом експлицитном изразу и онтолошком смислу.

\section{ЛИТЕРАТУРА}

Вајнрих 1989: Н. Vajnrih, Glagolsko vrijeme i raspravljani i pripovijedani svijet, y: (prir. Zlatko Kramarić) Revija XXIX, br. 2/3, Osijek, 211-221.

Делић 2006: Ј. Делић, Кажем ти тихо: ништа нам не треба, Нови Сад : Orpheus

Јовановић 2012: А. Јовановић, Љубав јака као смрт - о поеми „Кад дођеш у било који град” Матије Баћковића, у: (ур. J. 
Делић, Д. Хамовић) О песмама, поемама и поетиии Матије Бећковића, Београд, Требиње: Институт за књижевност и уметност, Учитељски факултет, Дучићеве вечери поезије, 283-310.

Лазић-Коњик 2009: И. Лазић-Коњик, О функционално-семантичкој категорији егзистениије у српском језику, Јужнословенски филолог, 2009, 359-374.

Лазић-Коњик 2011: И. Лазић-Коњик, Проспектуална аспеткуалност у семантичкој структури глагола постојана у српском језику, Српски језик, 2011, 671-681.

Ковачевић 2006: М. Ковачевић, Списи о стилу и језику, Бања Лук: Књижевна задруга

Ковачевић 2012: М. Ковачевић, Узрочно семантичко поље, Београд: Јасен

Николић 1998: Z. Bečanović-Nikolić, Hermeneutika i poetika (Teorija pripovedanja Pola Rikera), Beograd: Geopoetika Милосављевић 1995: П. Милосављевић, Бећковић, постмодернизам, неоромантизам, у: (М. Вукићевић, Н. Вуковић. М. Ковачевић (прир.) Поетика Матије Бећковића, Никшић: Филозофски факултет, 161-180.

Милошевић 1970, К. Milošević, Futur II i sinonimski oblici u savemenom srpskohrvatskom književnom jeziku, Sarajevo: Akademija nauke i umjetnosti Bosne i Hercegovine

Пантић 2002: М. Пантић, Пророчки стилски синдром у поезији Матије Бећковића, у (ур. Д. Хамовић) Матија Бећковић, песник, Краљево: Народна библиотека „Стефан Првовенчани".

Пантић 2001: М. Пантић, Песник који се смеје озбиљно, у: (прир. С. Ж. Марковић) Поезија Матије Бећковића, Београд: Задужбина Десанке Максимовић

Поповић 2008, Љ. Поповић, Језичка слика стварности, Београд: Филолошки факултет

Пипер 2005: П.Пипер и др., Синтакса савременога српског језика (проста реченииа), Београд: Институт за српски језик САНУ, Београдска књига, Матица српска

Поповић 2012: Р. Поповић, Поетички аспекти љубавног пјесништва Матије Бећковића, у: (ур. Ј. Делић, Д. Хамовић) $O$ 
песмама, поемама и поетиии Матије Бећковића, Београд,

Требиње: Институт за књижевност и уметност, Учитељски факултет, Дучићеве вечери поезије, 259-282.

Радуловић 2012: О. Радуловић, Визија Небеског Јерусалима у поеми Кад дођеш у било који град, у: (ур. Ј. Делић, Д. Хамовић) О песмама, поемама и поетици Матије Бећковића, Београд, Требиње: Институт за књижевност и уметност, Учитељски факултет, Дучићеве вечери поезије, 311-334.

РMC 1973, Речник Матице српске, књ. V, Нови Сад: Матица српска

Танасић 2012, С. Танасић, Из синтаксе српске реченице, Београд: Београдска књига

Штајгер 1978, E. Štajger, Umeće tumačenja, Beograd: Nolit Хајдегер 2007: M. Hajdeger, Bitak i vreme, Beograd: Službeni glasnik

Sonja M. Milovanović

\section{ABOUT THE EXISTENCE IN THE POEM KAD DOĐEŠ U BILO KOJI GRAD MATIJE BEČKOVIĆA}

The existential dimension is one of the differential lines of the poem Kad dođeš u bilo koji grad in relation to the other two Bećkovićs poem of the love triptych. It is expressed in two way: explicitly, which can be traces within the functional-semantic filed of existence, ad implicitly, through the notion of care, that is being-in-the-world. Accordingly, in the work we consider the phenomenon of existence interdisciplinary - through the linguistic realization of the category of existence and through its ontological implication. Since with the existence the closets link is a matter of time, its discussed with the regard to the speech situation, where it is divides into the debated and narrative world. It points to the dramatic existence of a narrator, to argumentative discourse and the inner composition of the text as a debated world. These result of the analysis are complementary to our starting point - that a 
certain tension of the action, or state, is indicated by the semantic of the verb to come, in the context of the introductory part, and in particular then in the whole poem. Since with time interference causative and conditional meanings of when-clause, the tension between inevitability and will is also reflected in the tension of resulting and processed plan of action. Also, the plot in the narrative flow of the poem refers to the internal dramatization of the beingin-the-world, through care, while semantic of the verb to know also indicate the existential layer as the primary in the position of the narrator.

Key words: existence, time, being, verbal aspect, drama, debated world 